\title{
Morphological and molecular identification and fungicide sensitivity assay of pathogens attacking guyabano (Annona muricata) in Philippines
}

\section{Alberto RT* and Otanes AT}

Department of Crop Protection, College of Agriculture, Central Luzon State University, Science City of Muñoz, Nueva Ecija, Philippines

Alberto RT, Otanes AT 2016 - Morphological and molecular identification and fungicide sensitivity assay of pathogens attacking guyabano (Annona muricata) in Philippines. Plant Pathology \& Quarantine 6(1), 60-79, Doi 10.5943/ppq/6/1/9

\begin{abstract}
This study characterizes the plant pathogens attacking guyabano fruits and leaves through morphological and molecular approaches and determines their sensitivity to fungicides. Three fungal pathogens were found on guyabano fruit, Colletotrichum gloeosporioides, C. acutatum and Fusarium chlamydosporum. Colletotrichum gloeosporioides was also found to infect the leaves. Molecular identification of the Colletotrichum species was carried out through amplification of rDNA ITS regions by using species specific primers: $C g$ Int for $C$. gloeosporioides and $C a$ Int 2 for C. acutatum in combination with ITS4 universal primer. Ver ITS primer was used on Fusarium species. All fungal pathogens were found to be highly pathogenic to guyabano fruits and leaves. Sensitivity assay revealed that all three pathogens were highly susceptible to captan, tebuconazole and difenoconazole + propiconazole.
\end{abstract}

Key words - Colletotrichum acutatum - Colletotrichum gloeosporioides - Fusarium chlamydosporum - molecular - morphological - sensitivity assay

\section{Introduction}

Soursop (Annona muricata L., family Anonaceae) also known as guyabano is indigenous to tropical North and South America. The fruits are prized for their pleasant, sub-acid aromatic and juicy flesh which consist of edible pulp and indigestible blade seeds. It is a major source of income for many farmers who cultivate them for fresh produce markets. It also provides nutrients and plays an important role in the diet of many people (Okigbo \& Obire 2009). The juice obtained from the fruit is used as diuretics and as a remedy for hematuria and urethritis. According to Nweke \& Ibiam (2012) the juice taken on an empty stomach is believed to alleviate liver diseases and leprosy. The principal interest in this plant is its strong anti-cancer effects, although it is effective for a number of medical conditions, its anti tumor effect is of most interest (Tabasum 2012).

This plant is a proven cancer remedy for cancers of all types, effectively targeting and killing malignant cells in 12 types of cancer, including colon, breast, prostate, lung and pancreatic cancer. The US National Cancer Institute performed the first scientific research in 1976 and their 
results showed that guyabano leaves and stems were found effective in attacking and destroying malignant cells. The guyabano leaves contain anti-cancer substances called annonaceous acetogenin, which can kill cancer cells without disturbing the healthy cells in the human body. In a study conducted by the Department of Science and Technology-Industrial Technology Development Institute (DOST-ITDI), it was found out that unripe guyabano has more flavonoids than its ripe form. Flavonoids may help in preventing cancer, allergies, infections, and viruses.

According to Jaramillio et al. (2000), oil extracted from the unripe fruit is mixed with olive oil and used externally against neuralgias, rheumatism and arthritic pains. As stated by Okigbo \& Obire (2009) national and international demand of guyabano has been growing at $3.8 \%$ per year and the potential for developing a profitable post-harvest industry is high. However, adverse physical and chemical changes in the fruit tissues can lower acceptability and nutritional value. Generally, loss in nutritional value of fruits is brought about by contamination by different microorganisms, either pre-harvest or after harvest. In this crop, McDonald (1970) also reported that fungal contamination is most prevalent and that fungi are their most important pathogens.

Diseases are often the most important constraints in the production of guyabano. Fungal pathogens are known to be responsible for the post-harvest deterioration of guyabano fruits (Setiawan et al. 2001). They debilitate the plants and directly reduced the yield and quality of fruits before and after they are harvested.

Gottsberger (1988) reported that post-harvest fungal soft rot pathogens of guyabano include Botryodiplodia theobromae, Colletotrichum gloeosporioides, Rhizopus stolonifer, R. nigricans, Aspergillus flavus and A. niger. Anthracnose (C. gloeosporioides) generates losses up to $90 \%$ in traditionally grown guyabano crops. The pathogen attacks the leaves, branches, flowers and fruits, producing black fruit rot, especially during rainy season (Alvarez et al. 2005).

The present study aimed to: (a) isolate, test for pathogenicity and identify the pathogens causing deterioration of guyabano leaves and fruits using morphological and molecular approaches; (b) determine which fungicides these pathogens are most sensitive to; and (c) determine which among the pathogens is the most destructive.

\section{Materials \& Methods}

\section{Collection, isolation and maintenance of isolates}

Infected guyabano fruit and leaf samples were collected from guyabano growing areas in the province of Nueva Ecija, Philippines. Fungal pathogens were isolated from heavily sporulating lesions following the tissue plating technique. Using a scalpel, 2 to $3 \mathrm{~mm}^{2}$ sections were cut from the advancing margin of the infected portion of the fruit and leaves. Cut sections were surface disinfected with $0.1 \%$ household bleach for 1 min and rinsed in 3 changes of sterile distilled water. Disinfected sections were blot dried in sterile tissue paper. Finally, four sections were planted equidistantly on potato dextrose agar (PDA) and incubated in darkness at $29^{\circ} \mathrm{C}$.

Mycelial growth arising from the planted tissues were isolated and grown into pure cultures on PDA slants. The isolates were maintained through mineral oil overlay prior to refrigeration.

\section{Pathogenicity test}

The isolated pathogens (Table 1) were inoculated onto healthy mature guyabano fruits (detached from the plant) and seedlings (for the leaves) to confirm their pathogenicity. Fungal isolates in Petri plates were grown in darkness for 14 days to induce sporulation. Cultures were flooded with $50 \mathrm{ml}$ sterile distilled water. The surface was scraped with a sterile wire loop to dislodge the spores and was then filtered through two layers of cheesecloth to remove mycelia. The spore density was adjusted to $5-6 \times 10^{5}$ spores/ml using a haemocytomer.

Spore suspension $(50 \mathrm{ml})$ was poured on three uninjured and injured (pin-pricked) inoculation sites marked with circles on the surface of the mature and healthy guyabano fruits. Three fruits were placed inside each improvised incubation chamber made up of a basin enclosed in a plastic bag. Three sterilized Petri plates (bottom) were put inside the basin to serve as a base for 
the fruits and to avoid water coming into contact with the fruits. Sterilized water $(200 \mathrm{ml})$ was poured to enhance humidity for faster sporulation.

Table 1 Source of fungal isolates used in the study.

\begin{tabular}{cll}
\hline \multicolumn{1}{c}{ Host } & \multicolumn{1}{c}{ Isolate } & \multicolumn{1}{c}{ Origin } \\
\hline \multirow{2}{*}{ Guyabano fruit } & Colletotrichum (1) & Magtanggol, Nueva Ecija, Philippines \\
& Colletotrichum (2) & Villa Cuizon, Nueva Ecija, Philippines \\
Guyabano leaves & Fusarium sp. & Matingkis, Nueva Ecija, Philippines \\
& Colletotrichum (3) & Magtanggol, Nueva Ecija, Philippines \\
& Colletotrichum (4) & Catalanacan, Nueva Ecija, Philippines \\
\hline
\end{tabular}

For guyabano leaves healthy seedlings were spray inoculated with $50 \mathrm{ml}$ spore suspension and covered with clean plastic bag. After $24 \mathrm{hr}$ of incubation, the plastic bags were removed and mist was applied every morning and afternoon for 7 days. Control fruits and leaves were inoculated with $50 \mathrm{ml}$ of sterile distilled water and incubated in a similar manner.

The set up for each pathogen was replicated three times. To satisfy Koch's Postulates, pathogens that showed positive effects on the fruit and leaves were re-isolated and re-examined for positive identification.

\section{Colony and spore morphology}

All the isolates were grown on PDA. The appearance of the colonies, the occurrence of sectors, and the vegetative and reproductive structures were described after 7 days of incubation. The cultures were incubated in darkness at $29^{\circ} \mathrm{C}$, and the diameter of the colony was recorded daily for 7 days. The colony characteristics that were described on the seventh day were texture, colour, zonation, transparency, nature of the growing margin and presence of conidial masses. For each isolate, spores were suspended in lactophenol cotton blue using a sterile needle. Length and width of 25 spores were measured and conidial shape was recorded at 400× magnification using bright field microscopy. Photomicrographs of the isolates were taken. The isolated pathogens were identified based on their colony and spore morphology and microscopic characters. These were referred to descriptions by Deacon (2006), Ou (1985), Pitt \& Hocking (2009) and Webster \& Weber (2007).

\section{Polymerase chain reaction (PCR)-based identification and characterization}

\section{Deoxyribonucleic acid (DNA) extraction}

Isolates were grown in $100 \mathrm{ml}$ potato dextrose broth for 5 days at $27^{\circ} \mathrm{C}$ in mechanical shaker $(120 \mathrm{rpm})$. The mycelia were filtered and oven dried for $24 \mathrm{hr}$ at $60^{\circ} \mathrm{C}$. Dried mycelia were ground into a fine powder using liquid nitrogen and the total genomic DNA extracted using DNeasy Plant Mini Kit (Qiagen, GmbH, Germany) following the manufacturer's protocol.

\section{Diagnostic PCR with species-specific primers}

CaInt2 (5'-GGGGAAGCCTCTCGCGG-3) specific for Colletotrichum acutatum and CgInt (5'-GGCCTCCCGCCTCCGGGCGG-3), specific for C. gloeosporioides were used in conjunction with the conserved primer ITS4. Each PCR product $(50 \mu \mathrm{l})$ contained $5 \mu \mathrm{l}$ of forward and reverse primers, $5 \mu \mathrm{l}$ of sterile distilled RNAse free water, $5 \mu$ l of QIAGEN ${ }^{\mathrm{TM}}$ Coral Load dye, $10 \mu \mathrm{l}(\mathrm{mM})$ diluted DNA and $25 \mu \mathrm{l}$ of QIAGEN ${ }^{\mathrm{TM}}$ mastermix. Amplification was carried out in Escoheathcare Swift Max pro Thermocycler with the following temperature profiles: 1 cycle of 5 min at $95^{\circ} \mathrm{C}, 25$ cycles of $30 \mathrm{~s}$ at $94^{\circ} \mathrm{C}, 30 \mathrm{~s}$ at $62^{\circ} \mathrm{C}$, and $2 \mathrm{~min}$ at $72^{\circ} \mathrm{C}$, ending with 1 cycle of $7 \mathrm{~min}$ at $72^{\circ} \mathrm{C}$. The PCR products $(50 \mu \mathrm{l})$ were verified through $1.5 \%$ agarose gels containing Invitrogen ${ }^{\mathrm{TM}} \mathrm{SYBR}^{\mathrm{R}}$ Safe DNA gel stain. The gel was checked by electrophoresis of $10 \mu 1$ of reaction product in $1 \mathrm{x}$ TBE buffer and visualized in Maestrogen LB-16 LED transilluminator. 


\section{Sequencing of rDNA ITS Region}

The amplicons (approximately 100 to $1000-\mathrm{bp}$ ) were purified by QIAquick ${ }^{\mathrm{R}}$ PCR purification kit according to manufacturer's protocols. The resulting DNA was eluted in $60 \mu 1$ of elution buffer. For each isolate, primers CaInt2 and CgInt were used for sequencing. Purified DNAs was sent for DNA sequencing at 1st Base Laboratories, lot 7-1 Jln SP 2/7 Tmn Serdang Perdana, Seksyen 2, 43300 Seri Kembangan, Selangor Malaysia.

\section{Sequence data management and analysis}

The sequence files were assembled and edited to resolve ambiguities using sequence scanner 1.0. Databases were searched for sequence similarities using NBCI BLAST program (http://www.blast.ncbi.nlm.gov). The consensus sequence for all isolates was compiled into a single file (FASTA format) and aligned using CLUSTALW2 (http://genome.nci.nih.gov/tools/reformat. html). Phylogenetic distances were calculated by the Neighbor Joining Method (Saitou \& Nei 1987) using the Nucleotide Maximum Composite Likelihood model with the use of Molecular Evolutionary Genetics Analysis (MEGA v.4.1) software (Tamura et al. 2007).

\section{Sensitivity assay}

The fungal pathogens were tested for their sensitivity to commercial fungicides based on the manufacturer's recommended rates (Table 2).

Table 2 Commercial fungicides used for sensitivity assay.

\begin{tabular}{|c|c|c|c|c|c|}
\hline & $\begin{array}{l}\text { Product } \\
\text { Name }\end{array}$ & $\begin{array}{l}\text { Active Ingredient } \\
\text { g/Kg }\end{array}$ & $\begin{array}{l}\text { Recommended } \\
\text { Rate }\end{array}$ & Manufacturer & Local Distributor \\
\hline 1. & Folicur $25 \mathrm{WP}$ & Tebuconazole (250) & $50-75 \mathrm{~g} / 100 \mathrm{~L}$ & Bayer CropSci. & Bayer CropSci. \\
\hline 2. & Agronil $75 \mathrm{WP}$ & Chlorothalonil (750) & $19.2-28.8 \mathrm{~g} / 16 \mathrm{~L}$ & Bayer CropSci. & $\begin{array}{l}\text { Integrated Crop. } \\
\text { Trading Corp. }\end{array}$ \\
\hline 3. & Antracol WP 70 & Propineb (70) & $50-65 \mathrm{~g} / 16 \mathrm{~L}$ & Bayer CropSci. & Bayer CropSci. \\
\hline 4. & Benomyl & Benomyl (500) & $1-2$ tbsp./16L & $\begin{array}{l}\text { Kajo Agro-Chemical } \\
\text { Company }\end{array}$ & Planters Products \\
\hline 5. & Kocide & Cupric hydroxide (538) & $2-6$ tbsp./16L) & $\begin{array}{l}\text { E.I du Pont de } \\
\text { Nemours \& Company }\end{array}$ & Du Pont Far East \\
\hline 6. & Vondozeb Plus & Mancozeb (800) & $3-6 \mathrm{tbsp} . / 16 \mathrm{~L}$ & Cerexagri B.V & Jardine Distribution \\
\hline 7. & $\begin{array}{l}\text { Daconil } 2787 \\
\text { WP } 75\end{array}$ & Chlorothalonil (750) & $19.2-28.8 \mathrm{~g} / 16 \mathrm{~L}$ & Bayer CropSci. & Bayer CropSci. \\
\hline 8. & Armure $300 \mathrm{EC}$ & $\begin{array}{l}\text { Difenoconazole (150) } \\
\text { Propiconazole (150) }\end{array}$ & $1.5-2.0 \mathrm{tbsp} / 16 \mathrm{~L}$ & Syngenta Phil. & Syngenta Phil.. \\
\hline & Captan $50 \mathrm{WP}$ & Captan (500) & $4-8$ tbsp./16L & Arvesta & Jardine Distribution \\
\hline 10. & Amistar $25 \mathrm{SC}$ & Azoxystrobin (250) & $1-2 \mathrm{tbsp} / 16 \mathrm{~L}$ & Syngenta Phil. & Syngenta Phil. \\
\hline 11. & Bavistin $50 \mathrm{DF}$ & Carbendazim (500) & $1-2 \mathrm{tbsp} / 16 \mathrm{~L}$ & BASF SE & $\begin{array}{l}\text { Biostadt Biostadt } \\
\text { Phil. }\end{array}$ \\
\hline 12. & Topsin-M $70 \mathrm{WP}$ & Thiophanate methyl (700) & $0.5-1 \mathrm{tbsp} / 16 \mathrm{~L}$ & Nippon-Soda Co. & $\begin{array}{l}\text { Trans World } \\
\text { Trading Co. }\end{array}$ \\
\hline
\end{tabular}

One hundred (100) $\mu 1$ of conidial suspension $\left(5-6 \times 10^{5} \mathrm{ml}^{-1}\right)$ of each isolate was placed separately into Petri plates. PDA was then poured into the plates, and swirled gently for an even distribution of the conidial suspension. Upon solidification, a flamed cork borer was used to create 5 wells (4 equidistant wells on the side and 1 on the centre to serve as the control) in the plate. Fungicide solution $(20 \mu \mathrm{l})$ was dropped into the 4 outside wells and sterile distilled water was dropped into the centre well as a control. The plates were incubated for 3 days at $28^{\circ} \mathrm{C}$ and the mean radius of the inhibition zone was measured across two perpendicular axes (minus the diameter of the well) for each fungicide concentration evaluated. Three replications of each isolate for each fungicide concentration was taken. 
A two factor factorial experiment arranged in a completely randomized design (CRD) with 12 treatments (Fungicides), using three rates, replicated three times for each isolate was used in the study.

\section{Data gathered}

Incidence and severity of disease were gathered from the pathogenicity test, while the zones of inhibition after 3 days of incubation were obtained in the sensitivity assay.

Symptom development was recorded and evaluated 72 hours after inoculation using the following parameters:

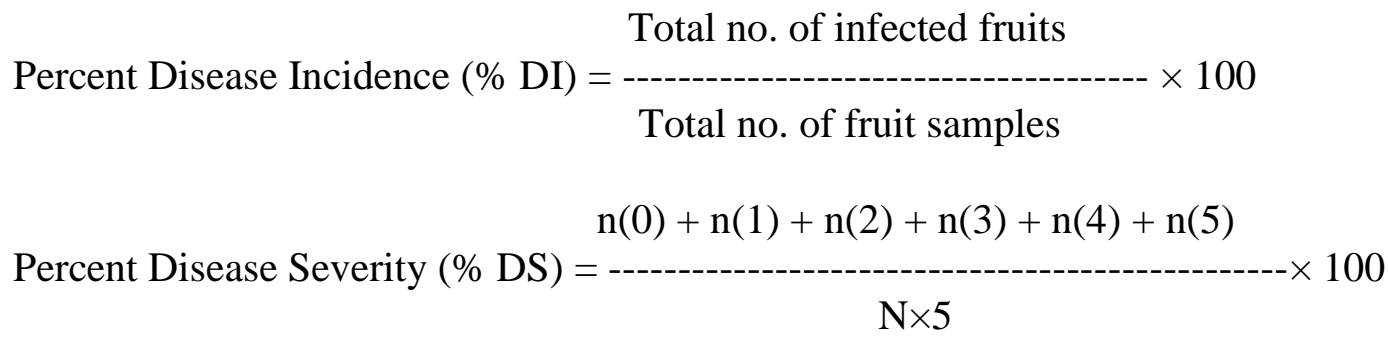

Where:

$\mathrm{n}=$ no. of infected fruits classified based on rating scale

$\mathrm{N}=$ total number of samples

Disease severity rating was rated from each fruit according to the scale below (Ilag \& Quimio 2006):

\begin{tabular}{cl}
\hline Scale & \multicolumn{1}{c}{ Fruit Rating } \\
\hline 0 & no infected portion \\
1 & less than $1 \%$ of commodity surface infected \\
2 & $1-5 \%$ of commodity surface infected \\
3 & $6-10 \%$ of commodity surface infected \\
4 & $11-20 \%$ of commodity surface infected \\
5 & over $20 \%$ of commodity surface infected \\
\hline
\end{tabular}

\section{Results and Discussion}

\section{Pathogenicity test}

\section{Disease incidence $(\%)$ in guyabano fruits and leaves}

Symptoms developed on the injured guyabano fruits 72 hours after inoculation. Symptoms of rotting were evident in all inoculated areas. All the isolates were highly pathogenic to the guyabano fruits (100\% disease incidence) as compared to guyabano fruits inoculated with sterile distilled water (Table 3). For the uninjured fruits, no changes and no mycelial growth was observed.

Disease incidence on guyabano leaves was observed as early as 24 hours after inoculation. Symptoms of brown papery lesions were very evident on inoculated leaves. Control leaves inoculated with sterile distilled water remain uninfected (Table 3). 
Table 3 Disease incidence (DI \%) of guyabano fruits and leaves 3 days after inoculation.

\begin{tabular}{lr}
\hline \multicolumn{1}{c}{ Isolated Fungal Pathogen } & \%DI \\
\hline Fruits & $100^{\mathrm{a}}$ \\
\hline Colletotrichum gloeosporioides (1) & $100^{\mathrm{a}}$ \\
Colletotrichum acutatum & $100^{\mathrm{a}}$ \\
Fusarium chlamydosporum. & $0^{\mathrm{b}}$ \\
Sterilized distilled water & $100^{\mathrm{a}}$ \\
\hline Leaves & $100^{\mathrm{a}}$ \\
\hline Colletotrichum gloeosporioides (2) & $0^{\mathrm{b}}$ \\
Colletotrichum gloeosporioides (3) & \\
Sterilized distilled water & \\
\hline
\end{tabular}

\section{Disease severity $(\%)$ in guyabano fruits and leaves}

At 3 days after inoculation, fruit deterioration reached $88 \%$ in fruit that was inoculated with Colletotrichum acutatum. Fruits that were inoculated with $C$. gloeosporioides (1) and Fusarium chlamydosporum reached severity of $82 \%$ and $86 \%$, respectively. Control fruits inoculated with sterile distilled water remained unaffected. Guyabano leaves collected from Magtanggol, inoculated with C. gloeosporioides (2) reached a severity of 59\% and leaves collected from Catalanacan inoculated with $C$. gloeosporioides (3) reached a severity of $77 \%$. The control leaves remained unaffected (Table 4).

Table 4 Disease severity (DS \%) of guyabano fruits and leaves 3 days after inoculation.

\begin{tabular}{lc}
\hline \multicolumn{1}{c}{ Isolated Fungal Pathogen } & \%DS \\
\hline Fruits & \\
\hline Colletotrichum gloeosporioides (1) & $82.22^{\mathrm{a}}$ \\
Colletotrichum acutatum & $88.88^{\mathrm{a}}$ \\
Fusarium chlamydosporum. & $86.66^{\mathrm{a}}$ \\
Sterilized distilled water & $0.00^{\mathrm{b}}$ \\
\hline Leaves & \\
\hline Colletotrichum gloeosporioides (2) & $59.89^{\mathrm{b}}$ \\
Colletotrichum gloeosporioides (3) & $77.78^{\mathrm{a}}$ \\
Sterilized distilled water & $0.00^{\mathrm{c}}$ \\
\hline
\end{tabular}

Pathogenicity tests showed that Colletotrichum gloeosporioides (1), C. acutatum and Fusarium chlamydosporum caused symptoms of deterioration in guyabano fruits. $C$. gloeosporioides (2) and C. gloeosporioides (3) were also proven to be the causal agent of anthracnose in the leaves. Pathogenicity test also shows that all isolates were highly virulent to cause disease in guyabano fruits and leaves that requires sensitivity test to fungicides.

Incidence and severity are the tools for measuring the diseases. Awa et al. (2012) observed that although fruit anthracnose was prevalent in all mango growing areas surveyed, the occurrence and severity was probably more influenced by environmental conditions and cultural practices rather than climatic factors in the areas. Fruit yield was lowest in areas with highest anthracnose disease occurrence and severity an indication that anthracnose disease phenomenon has negative correlation with fruit yield. This phenomenon was largely influenced by environmental conditions and cultural practices.

Based from the study of Ritchie (2000), on brown rot of stone fruits, the amount of inoculum is very important in determining the severity of brown rot. Warm, wet or humid weather 
during the 2 to 3 week period prior to harvest increases disease severity because it increases both the level of inoculum and the amount of infection. According to Hossain et al. (2010) on their survey on major diseases of fruits and vegetables, the highest disease incidence was recorded from soft rot of potato. The lowest fruit disease incidence was recorded from anthracnose of banana and papaya. They concluded that the incidence and severity of vegetables and fruits can differ in the different locations because of the existence of strains of the pathogen.

\section{Morphological characteristics of pathogens attacking guyabano fruits and leaves}

\section{Colletotrichum gloeosporioides (1)}

Circular, dark sunken anthracnose lesions were observed on the guyabano fruits collected from Magtanggol. The circular spot sometimes coalesced to form irregular spots (Fig. 1a).

On PDA colonies were $66 \mathrm{~mm}$ in diameter after 7 days at $29^{\circ} \mathrm{C}$, cottony, dense, initially white or cream white to pale grey mycelium with a few conidial masses was observed (Fig. 1b).

Conidia were ovoid to oblong and rounded at each end, slightly curved dumbbell shaped $13.4 \mu \mathrm{m}$ in length and $5 \mu \mathrm{m}$ in width (Fig. 1c).

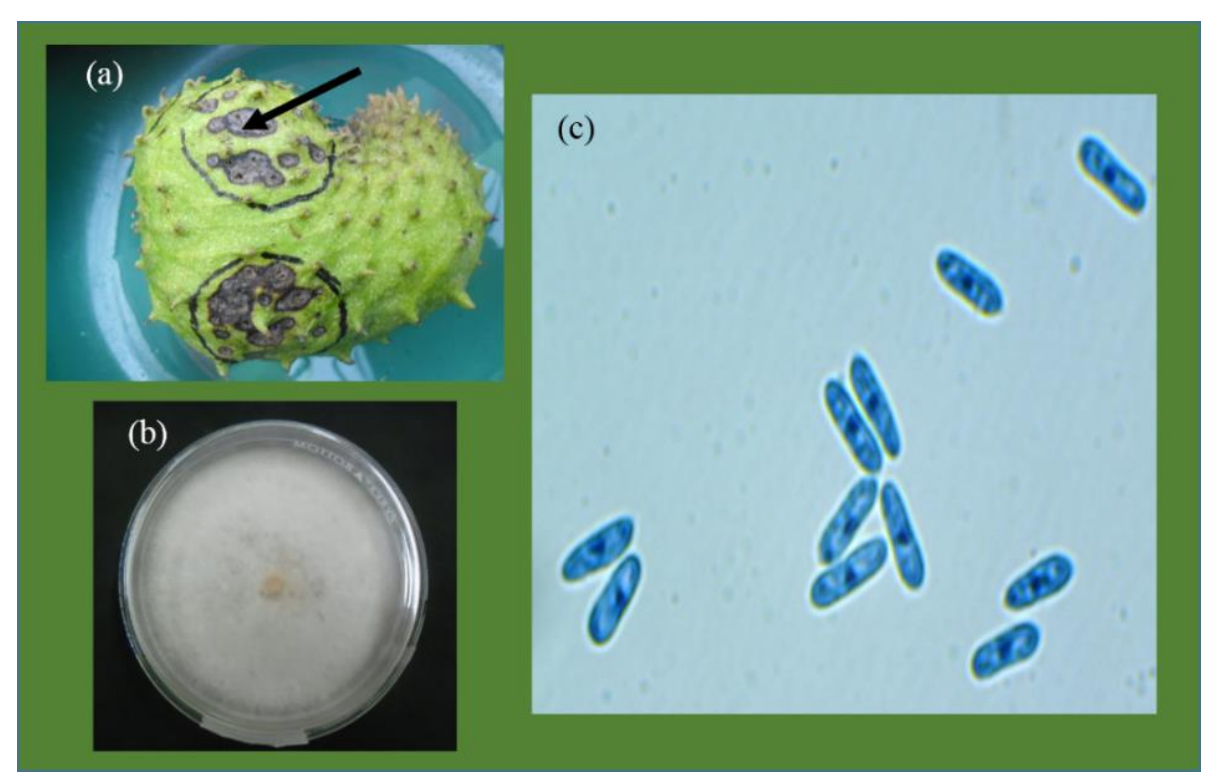

Fig 1 - Colletotrichum gloeosporioides (1). a, growing on the surface of a guyabano fruit. b, 14day-old culture. c, photomicrograph showing conidia of a 14-day-old culture (400x).

\section{Colletotrichum acutatum}

Growth observed from the guyabano fruit collected from Villa Cuison began as small, dark brown necrotic and sunken lesions that continue to enlarge as the fruits ripen (Fig. 2a).

On PDA colonies were $67.33 \mathrm{~mm}$ in diameter after 7 days at $29^{\circ} \mathrm{C}$, dense, thick and fluffy textured. The cultures had cottony, white to orange mycelium with orange conidial masses produced in concentric rings (Fig. 2b).

Conidia were $13.2 \mu \mathrm{m}$ in length and $2.8 \mu \mathrm{m}$ in width, cylindrical with rounded ends but sometimes slightly fusiform (Fig. 2c). 


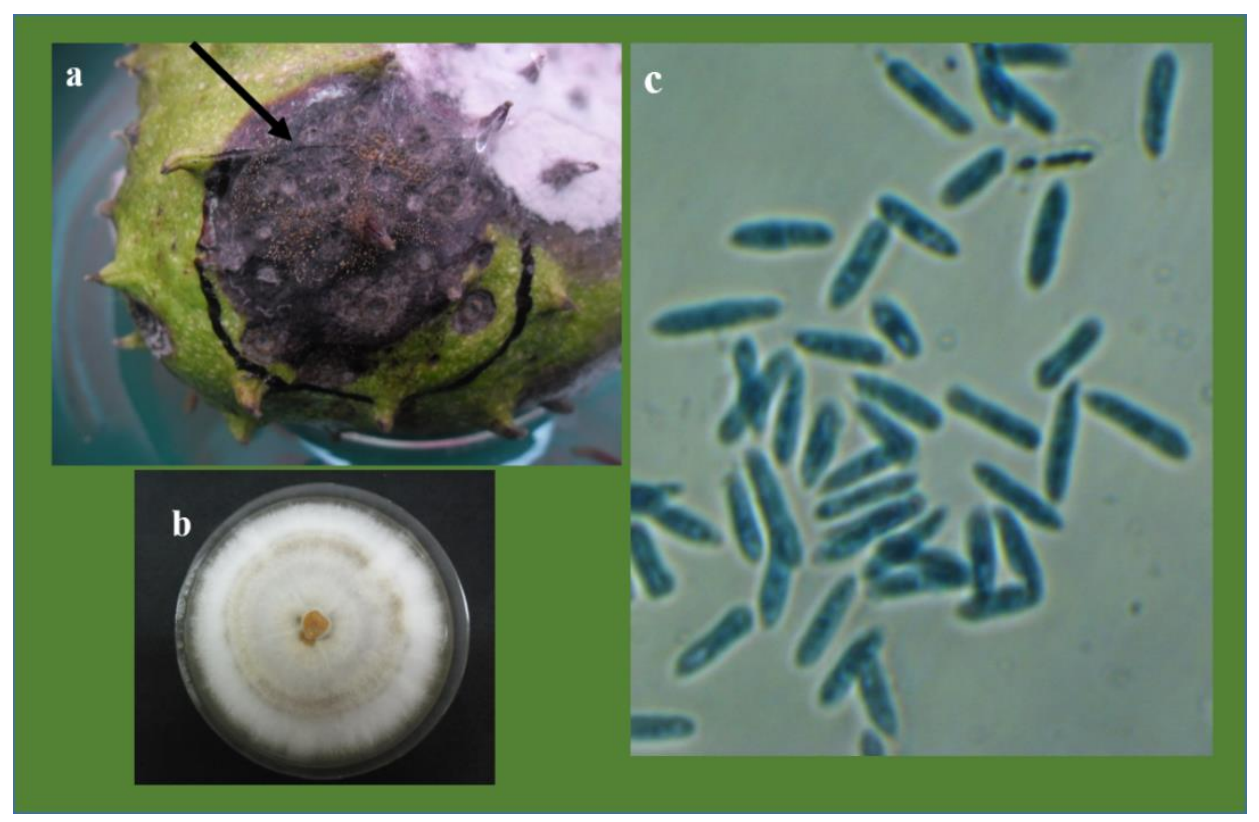

Fig 2 - Colletotrichum acutatum. a, growing on the surface of guyabano fruit. b, 14-day-old culture. c, photomicrograph of conidia of a 14-day-old culture (400x).

\section{Fusarium chlamydosporum}

Black necrotic slightly sunken lesion was observed on the surface of the guyabano fruit. Necrotic lesion appeared as white to greyish on the injured part of the fruit surrounded by black necrotic lesion (Fig. 3a).

On PDA colonies were $57.5 \mathrm{~mm}$ in diameter after 7 days at $29^{\circ} \mathrm{C}$, white to yellow mycelium turns fluffy, dense and cottony (Fig. 3b).

Macro-conidia were $20.6 \mu \mathrm{m}$ in length and $3.9 \mu \mathrm{m}$ in width, slightly curved, fusiform, pointed at the tip with 3-4 septa (Fig. 3c).

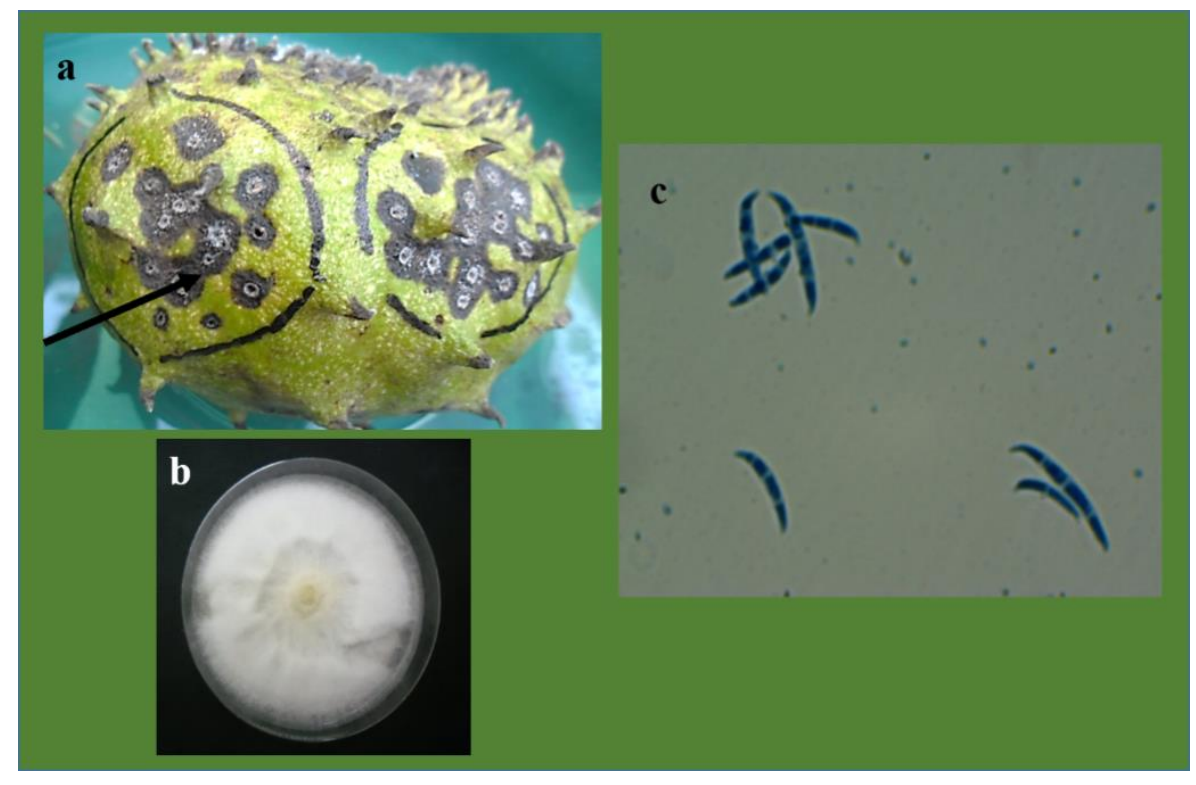

Fig 3 - Fusarium chlamydosporum. a, growing on the surface of guyabano fruit. b, 14-day-old culture. c, photomicrograph of conidia of a 14-day-old culture (400x). 


\section{Colletotrichum gloeosporioides (2)}

Symptoms on guyabano leaves collected from Magtanggol appeared as brown angular lesion and paper-thin (Figs 4a.1, 4a.2).

On PDA colonies were $63 \mathrm{~mm}$ in diameter after 7 days at $29^{\circ} \mathrm{C}$, dense, cottony, initially white turns to grey mycelium produced orange conidial masses at the center (Fig. 4b). $4 c)$.

Conidia were $14.4 \mu \mathrm{m}$ in length and $4.3 \mu \mathrm{m}$ in width, cylindrical with rounded ends (Fig.

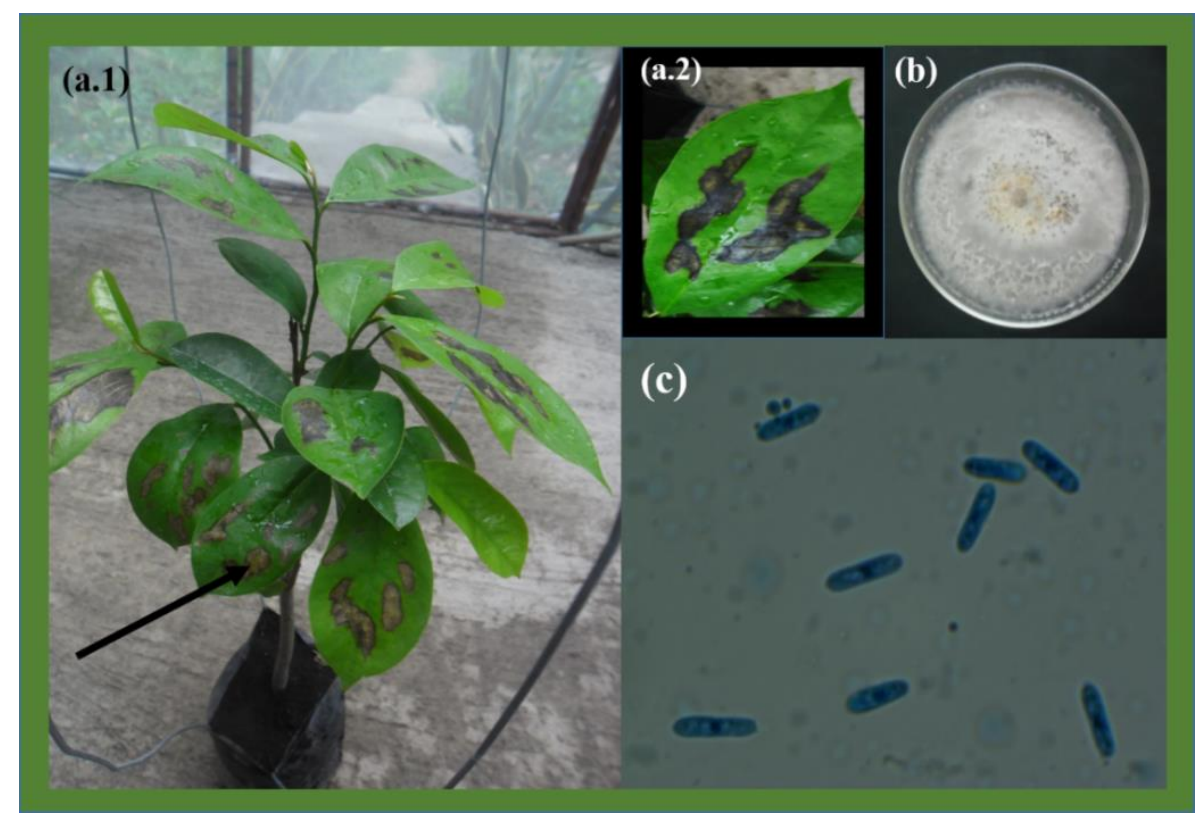

Fig 4 -Colletotrichum gloeosporioides (2). a.1, growing on the surface of the leaves. a.2, close-up of leaf angular lesion. b, 14 day old culture. c, photomicrograph showing conidia of a 14-day-old culture $(400 \times)$.

\section{Colletotrichum gloeosporioides (3)}

The leaves collected from Catalanacan showed symptoms as large, brown papery patches on the surface of the guyabano leaves (Fig. 5a).

On PDA colonies were $52 \mathrm{~mm}$ in diameter after 7 days at $29^{\circ} \mathrm{C}$, appeared initially white or cream white becoming pale grey with dark or orange center, dense, cottony, thick and fluffy (Fig. $5 b)$.

Conidia were $14.8 \mu \mathrm{m}$ in length and $4.1 \mu \mathrm{m}$ in width, cylindrical with obtuse ends (Fig. 5d).

Morphological identification of guyabano isolates was based on phenotypic traits such as colony appearance and character of vegetative and reproductive structures. The results of culture studies were almost fully consistent with description of Smith \& Black (1990). The conidia of Colletotrichum acutatum are elliptic-fusiform in shape, whereas conidia of C. gloeosporioides are cylindrical with obtuse ends (Baxter et al. 1983, Dyko \& Mordue 1979, Smith \& Black 1990). However, a definite identification of Colletotrichum species based on morphology is difficult because isolates have overlapping ranges of conidial and colony characteristics and because the variation in morphology is accepted for isolates within a species (Sutton 1992). Fusarium species emphasizes the need for accurate identification on the species level. According to Leslie \& Summerell (2006), Fusarium species determined can be identified based on morphology alone. However, identification based on molecular data is considered more reliable and accurate than morphological identification and has become much more important in diagnostics of the fungi from the genus Fusarium. 


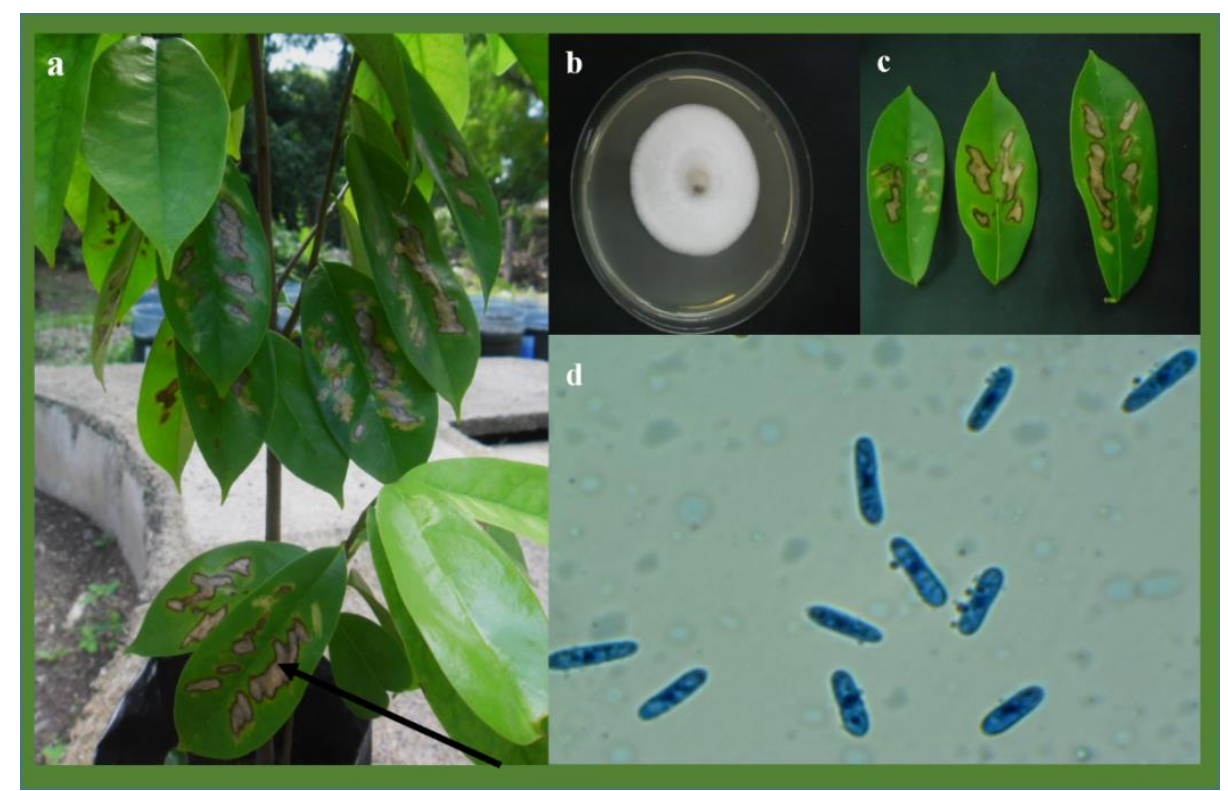

Fig 5 - Colletotrichum gloeosporioides (3). a, growing on the surface of the leaves. b, 14-day-old culture. c, close-up of anthracnose lesion. d, photomicrograph showing conidia from 14-day-old culture (400x).

\section{Molecular characterization of pathogens attacking Guyabano}

DNA extraction was done by growing the isolates in potato dextrose broth for 5 days in orbital shaker to increase oxygenation of mycelia (Fig. 6).

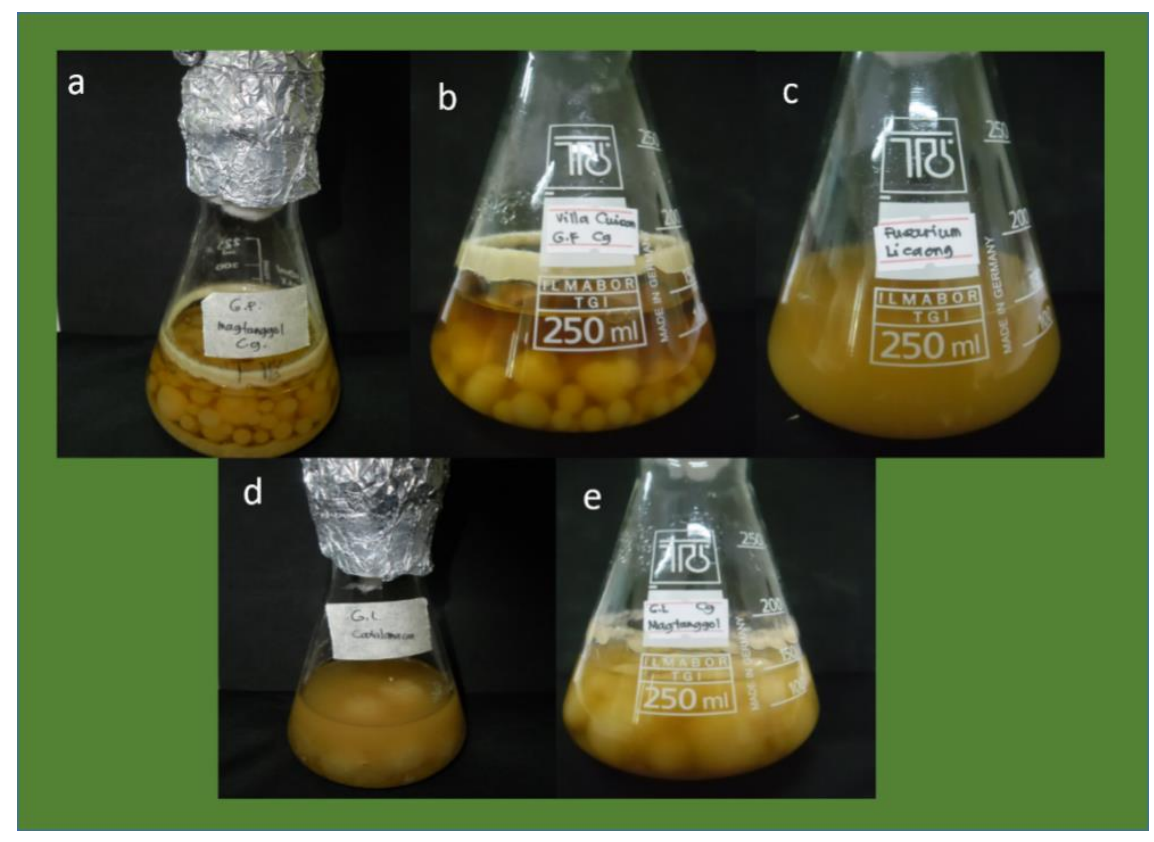

Fig 6 - Isolates from guyabano fruits and leaves grown on PDB. a, Colletotrichum gloeosporioides (1). b, C. acutatum. c Fusarium chlamydosporum. d, C. gloeosporioides (2). e, C. gloeosporioides (3).

The species-specific primer CaInt2 for Colletotrichum acutatum and $C g$ Int for $C$. gloeosporioides in conjunction with ITS4 primer amplified a 450-bp and 490-bp fragments from genomic DNA of $C$. acutatum and $C$. gloeosporioides, respectively, thus confirming the species 
identity. Universal primer Ver ITS for Fusarium chlamydosporum amplified a 250-bp fragment (Fig. 7).

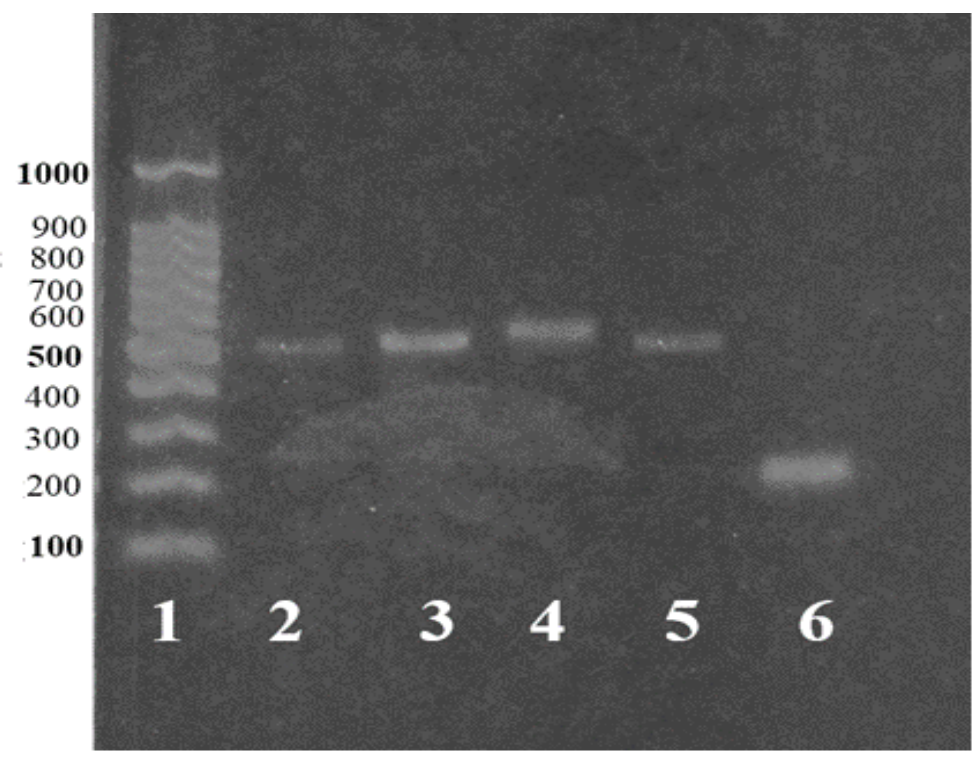

Fig 7 - Amplification of DNA fragments from Colletotrichum and Fusarium isolates. lanes 2 and 5; C. gloeosporioides from guyabano leaves, lanes 3 and 4; C. gloeosporioides and C. acutatum from guyabano fruits and, lane 6; Fusarium chlamydosporum isolate from guyabano fruit. 1; Molecular DNA Ladder (100-1000-bp).

\section{Phylogenetic analysis}

The aligned sequence of Colletotrichum gloeosporioides isolated from guyabano fruit when compared to different Colletotrichum species in GenBank were found 99\% similarity to the identity of C. gloeosporioides (JX902437.1). Phylogenetic analysis showed that the Colletotrichum isolate was phylogenetically related to $C$. gloeosporiodes present in database. The level of confidence of the NJ tree was well supported with $98 \%$ bootstrap value clustered to the main clades of $C$. gloeosporioides (JX902437.1, KC209100.1, KJ152170.1, KC122768.1 and KF923853.1), C. fragariae (KC209101.1) and Glomerella cingulata (KF923855.1) and clustered separately to the Phytophthora capsici as an out group from the phylogenetic tree (Fig. 8).

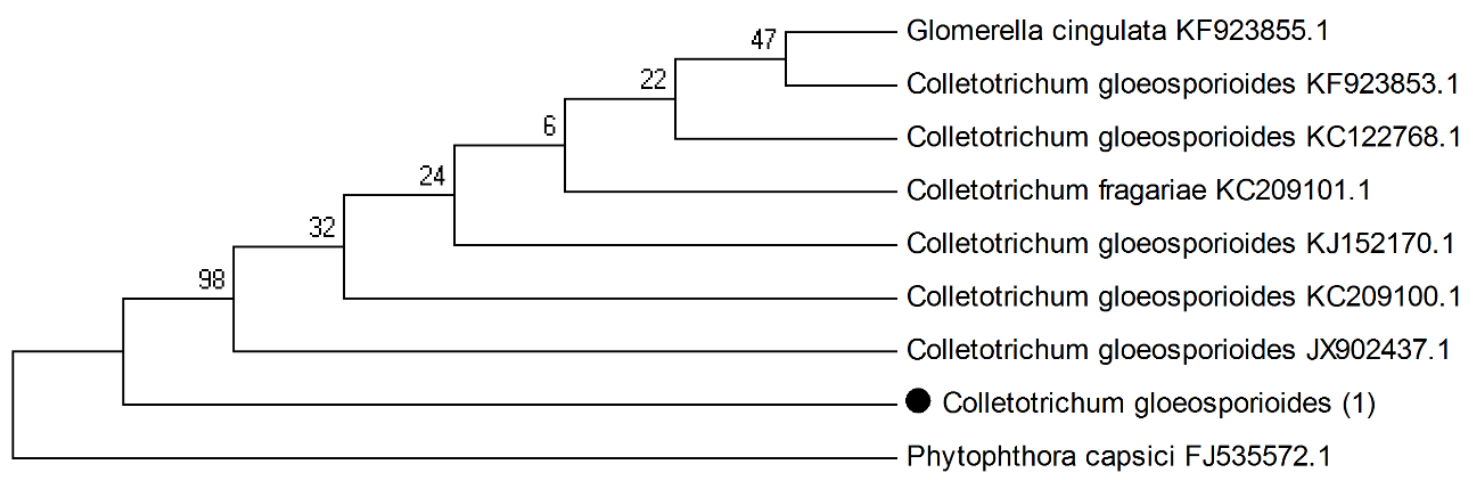

Fig 8 - Phylogenetic tree of various Colletotrichum species based on DNA sequences. Values from 1000 bootstrap replications are shown above tree branches. Code after the species names are the NCBI accession number. 
Colletotrichum acutatum in guyabano fruit isolates were matched to Glomerella acutata with $99 \%$ similar identity present in data base. The $C$. acutatum isolates also clustered to the clades of G. acutata (DQ454010.1) based on NJ tree analysis supported with 99\% bootstrap value (Fig. 9).

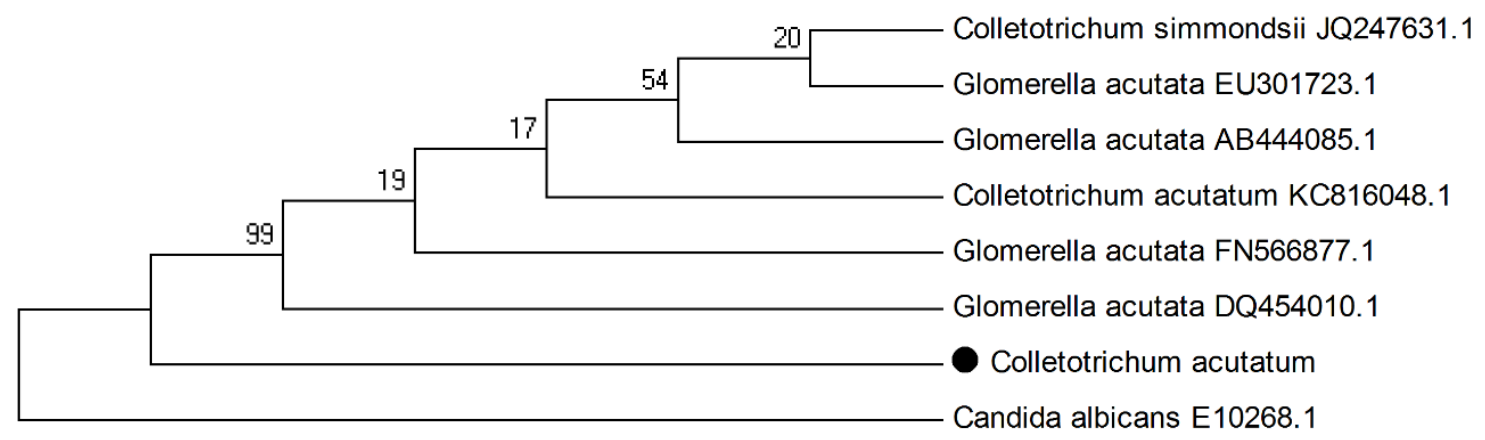

Fig 9 - Phylogenetic tree of various Colletotrichum species based on DNA sequences. Values from 1000 bootstrap replications are shown above tree branches. Code after the species names are the NCBI accession number.

Fusarium chlamydosporum generated sequences with $99 \%$ similarity to $F$. chlamydosporum (KF494035.1). Fig. 10 showed the clades supported with 89\% bootstrap value of $F$. chlamydosporum isolates that clustered to the group of $F$. chlamydosporum (KF494035.1, KF494034.1 and KF494033.1) and F. solani (KF918580.1).

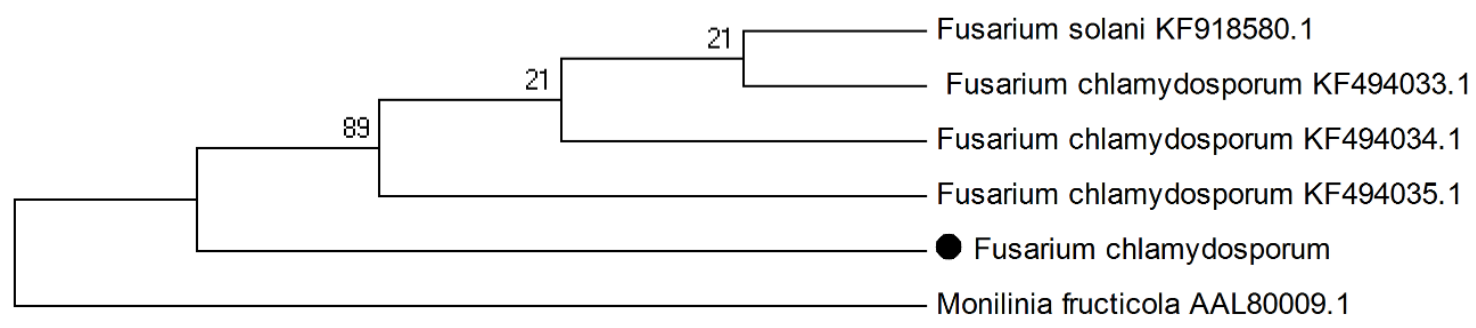

Fig 10 - Phylogenetic tree of various Fusarium species based on DNA sequences. Values from 1000 bootstrap replications are shown above tree branches. Code after the species names are the NCBI accession number.

Analysis of fungal pathogens of guyabano leaves from Magtanggol and Catalanacan showed that both isolates (2 and 3) were C. gloeosporioides with C. gloeosporioides (2) closely related to $C$. gloeosporioides JF487788.1 and clustered within the group of $C$. gloeosporioides with 99\% bootstrap value (KJ168597.1, JX258684.1, KC010537.1, KC565728.1 and KF923871.1) and Glomerella cingulata DQ062671.1 which separated from Tilletia barclayana (AY837518.1) as out group (Fig. 11). 


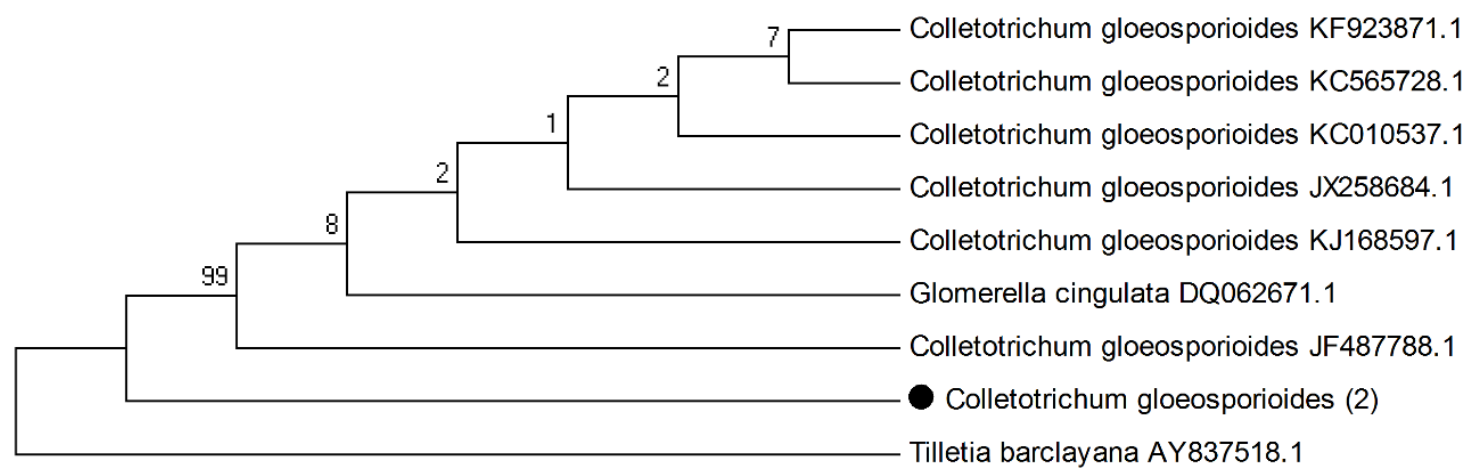

Fig 11 - Phylogenetic tree of various Colletotrichum 2 species based on DNA sequences. Values from 1000 bootstrap replications are shown above tree branches. Code after the species names are the NCBI accession number.

C. gloeosporioides (3) was closest to C. gloeosporioides (KC209102.1) with 99\% similarity in the database. The clades of the tree supported with $100 \%$ bootstrap value includes $C$. gloeosporioides (KC209102.1, KF907247.1, HQ328013.1, KF923871.1, KJ152170.1 and JX231012.1) and Glomerella cingulata (JX139533.1) with an out group using Phytophthora capsici (FJ535572.1) that separates the clades of the NJ tree (Fig. 12).

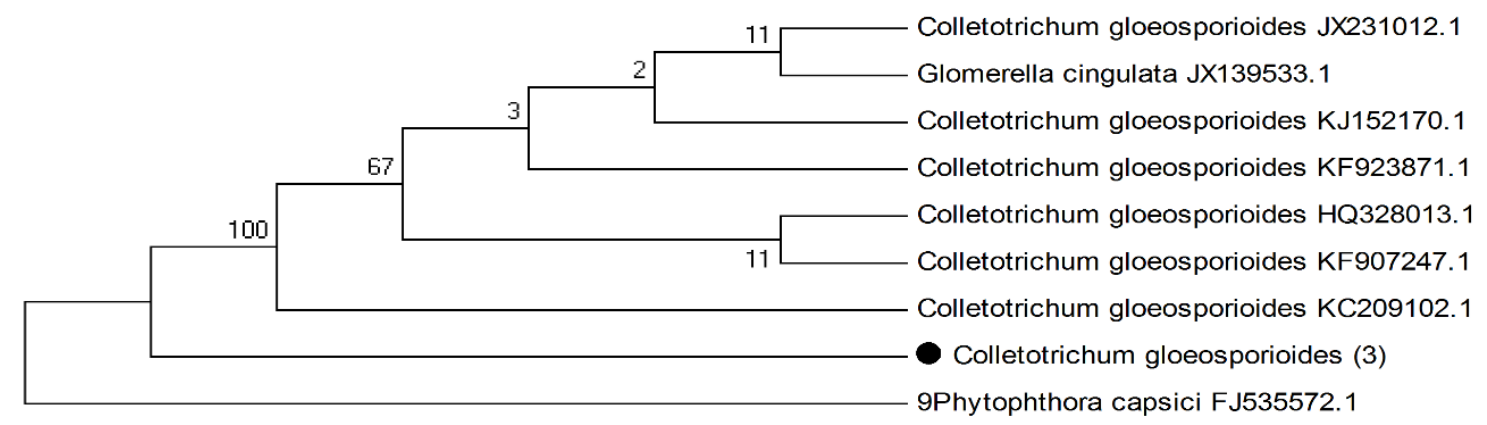

Fig 12 - Phylogenetic tree of various Colletotrichum 3 species based on DNA sequences. Values from 1000 bootstrap replications are shown above tree branches. Code after the species names are the NCBI accession number.

A definite identification of Colletotrichum species based on morphology is difficult because isolates have overlapping ranges of conidial and colony characteristics, and because the variation in morphology is accepted for isolates within a species (Sutton 1992). Fusarium species emphasizes the need for accurate identification on the species level. According to Leslie \& Summerell (2006), Fusarium species can be identified based on morphology alone. However, identification based on molecular data is considered more reliable and accurate than morphological identification and has become much more important in diagnostics of the fungi from the genus Fusarium.

Based from the results, molecular analyses indicated that Colletotrichum species from GenBank was phylogenetically related to the Colletotrichum species isolated from guyabano fruit and leaves. According to Johnston \& Jones (1997), C. acutatum, Fusarium. sp. and Glomerella miyabeana, a pathogen of willow, were found to be related phylogenetically to $C$. acutatum when using the D1-D2 LSU rDNA region.

Alvarez et al. (2005) also confirmed that Colletotrichum gloeosporioides and C. acutatum are associated with anthracnose in guyabano. 


\section{Sensitivity assay}

\section{Colletotrichum gloeosporioides (1)}

Difenoconazole + propiconazole and captan were highly effective against Colletotrichum gloeosporioides (1) as shown by a large zone of inhibitions ranging from $19.9 \mathrm{~mm}$ to $21.0 \mathrm{~mm}$ and 12.7-14.6 mm respectively 3 days after incubation in all concentrations. This was followed by tebuconazole that showed sensitivity in the two concentrations but to a lesser degree in recommended rate less $25 \%$. Cupric hydroxide and thiophanate methyl were less effective against C. gloeosporioides in all rates of the fungicides tested (Table 5). It also showed sensitivity to propineb at recommended rate $+25 \%$ but with minimal effects on the other two concentrations (Fig. 13).

Table 5 Zone of inhibition of the 12 fungicides tested against Colletotrichum gloeosporioides (1) in guyabano fruit after 3 days incubation.

\begin{tabular}{lccc}
\hline \multicolumn{1}{c}{ Fungicide } & \multicolumn{3}{c}{ Zone of Inhibition (mm) } \\
\cline { 2 - 4 } & $\begin{array}{c}\text { Recommended } \\
\text { Rate }\end{array}$ & $\begin{array}{c}\text { Recommended } \\
\text { Rate - 25\% }\end{array}$ & $\begin{array}{c}\text { Recommended } \\
\text { Rate + 25\% }\end{array}$ \\
\hline 1. Tebuconazole & $12.60^{\mathrm{b}}$ & $7.00^{\mathrm{cd}}$ & $9.83^{\mathrm{b}}$ \\
2. Chlorothalonil (1) & $1.13^{\mathrm{de}}$ & $3.90^{\mathrm{cdef}}$ & $4.69^{\mathrm{c}}$ \\
3. Propineb & $6.02^{\mathrm{c}}$ & $3.17^{\mathrm{def}}$ & $10.48^{\mathrm{b}}$ \\
4. Benomyl & $2.17^{\mathrm{de}}$ & $7.27^{\mathrm{c}}$ & $5.40^{\mathrm{c}}$ \\
5. Cupric hydroxide & $0.00^{\mathrm{e}}$ & $0.00^{\mathrm{f}}$ & $0.00^{\mathrm{d}}$ \\
6. Mancozeb & $3.33^{\mathrm{d}}$ & $3.25^{\mathrm{def}}$ & $2.73^{\mathrm{cd}}$ \\
7. Chlorothalonil (2) & $7.79^{\mathrm{c}}$ & $4.27^{\mathrm{cde}}$ & $5.67^{\mathrm{c}}$ \\
8. DP* & $20.88^{\mathrm{a}}$ & $19.94^{\mathrm{a}}$ & $21.00^{\mathrm{a}}$ \\
9. Captan & $14.58^{\mathrm{b}}$ & $12.86^{\mathrm{b}}$ & $12.73^{\mathrm{b}}$ \\
10. Azoxystrobin & $1.88^{\mathrm{de}}$ & $0.29^{\mathrm{f}}$ & $0.96^{\mathrm{d}}$ \\
11. Carbendazim & $0.27^{\mathrm{e}}$ & $1.00^{\mathrm{ef}}$ & $0.79^{\mathrm{d}}$ \\
12. Thiophanate Methyl & $0.00^{\mathrm{e}}$ & $0.00^{\mathrm{f}}$ & $0.00^{\mathrm{d}}$ \\
13. Control & $0.00^{\mathrm{e}}$ & $0.00^{\mathrm{f}}$ & $0.00^{\mathrm{d}}$ \\
\hline
\end{tabular}

*DP= Difenoconazole + propiconazole

Means with a common letter are not significantly different

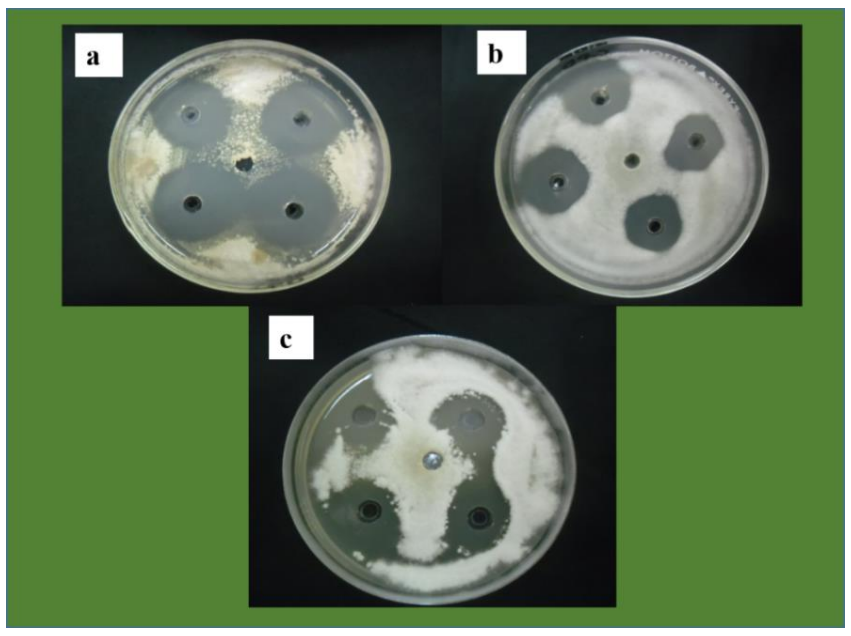

Fig 13 - Zone of inhibition of the three best fungicides against Colletotrichum gloeosporioides. a, Difenoconazole + propiconazole. b, Captan. c, Tebuconazole. 
The three best fungicides against Colletotrichum gloeosporioides (1) were captan, difenoconazole + propiconazole and tebuconazole. The recommended rate is the best to use because the pathogens show high sensitivity to this rate.

\section{Colletotrichum acutatum}

Captan was most effective against Colletotrichum acutatum with an inhibition zone ranging from $14.5 \mathrm{~mm}-18.8 \mathrm{~mm}$ in diameter (Table 6).

Table 6 Zone of inhibition ( $\mathrm{mm}$ ) of the 12 fungicides tested against Colletotrichum acutatum in guyabano fruit after 3 days incubation.

\begin{tabular}{lccc}
\hline \multirow{2}{*}{ Fungicide } & \multicolumn{3}{c}{ Zone of Inhibition (mm) } \\
\cline { 2 - 4 } & $\begin{array}{c}\text { Recommended } \\
\text { Rate }\end{array}$ & $\begin{array}{c}\text { Recommended } \\
\text { Rate }-\mathbf{2 5 \%}\end{array}$ & $\begin{array}{c}\text { Recommended } \\
\text { Rate + 25\% }\end{array}$ \\
\hline 1. Tebuconazole & $0.42^{\mathrm{f}}$ & $0.17^{\mathrm{c}}$ & $0.71^{\mathrm{e}}$ \\
2. Chlorothalonil (1) & $3.71^{\mathrm{d}}$ & $3.46^{\mathrm{b}}$ & $6.83^{\mathrm{c}}$ \\
3. Propineb & $1.08^{\mathrm{f}}$ & $2.04^{\mathrm{c}}$ & $0.00^{\mathrm{e}}$ \\
4. Benomyl & $0.00^{\mathrm{f}}$ & $1.04^{\mathrm{c}}$ & $0.00^{\mathrm{e}}$ \\
5. Cupric hydroxide & $0.00^{\mathrm{f}}$ & $0.00^{\mathrm{c}}$ & $0.00^{\mathrm{e}}$ \\
6. Mancozeb & $2.50^{\mathrm{ef}}$ & $0.00^{\mathrm{c}}$ & $3.06^{\mathrm{d}}$ \\
7. Chlorothalonil (2) & $3.15^{\mathrm{de}}$ & $1.42^{\mathrm{bc}}$ & $3.04^{\mathrm{d}}$ \\
8. DP* & $14.58^{\mathrm{b}}$ & $16.08^{\mathrm{a}}$ & $15.00^{\mathrm{b}}$ \\
9. Captan & $16.67^{\mathrm{a}}$ & $14.54^{\mathrm{a}}$ & $18.81^{\mathrm{a}}$ \\
10. Azoxystrobin & $7.50^{\mathrm{c}}$ & $1.96^{\mathrm{bc}}$ & $3.71^{\mathrm{d}}$ \\
11. Carbendazim & $0.58^{\mathrm{f}}$ & $0.29^{\mathrm{c}}$ & $0.25^{\mathrm{e}}$ \\
12. Thiophanate methyl & $0.50^{\mathrm{f}}$ & $0.33^{\mathrm{c}}$ & $0.67^{\mathrm{e}}$ \\
13. Control & $0.00^{\mathrm{f}}$ & $0.00^{\mathrm{c}}$ & $0.00^{\mathrm{e}}$ \\
\hline
\end{tabular}

$* \mathrm{DP}=$ Difenoconazole + propiconazole.

Means with a common letter are not significantly different

Colletotrichum acutatum was also highly sensitive to difenoconazole + propiconazole in all concentrations with the zone of inhibition ranging $14.6 \mathrm{~mm}$ to $16.1 \mathrm{~mm}$ in diameter (Fig. 14). The remaining fungicides showed minimal effects against $C$. acutatum.

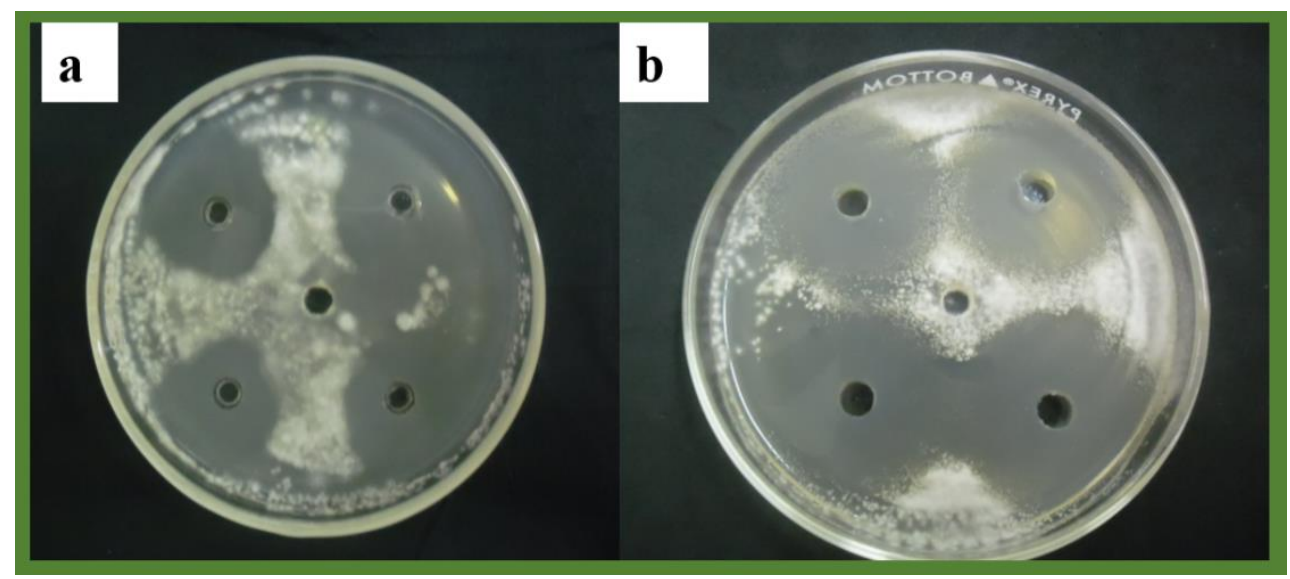

Fig 14 - Zone of inhibition of the two best fungicides against Colletotrichum acutatum isolated from guyabano fruits. a, Difenoconazole + propiconazole. $b$, Captan. 


\section{Fusarium chlamydosporum}

The biggest inhibition zone recorded against Fusarium chlamydosporum was on difenoconazole + propiconazole $(16-18.23 \mathrm{~mm})$ and sensitivity of the isolate in all concentrations was also seen. Captan was also highly effective with the zone of inhibition of $F$. chlamydosporum ranging from 10.69-17.98 $\mathrm{mm}$ in diameter. Azoxystrobin shows its efficacy in using the recommended rate $+25 \%$ with its zone of inhibition of $9.25 \mathrm{~mm}$ diameter. $F$. chlamydosporum showed no sensitivity to tebuconazole, benomyl, cupric hydroxide and thiophanate methyl and little sensitivity to other fungicides tested (Table 7). The two best fungicides are shown on Fig. 15.

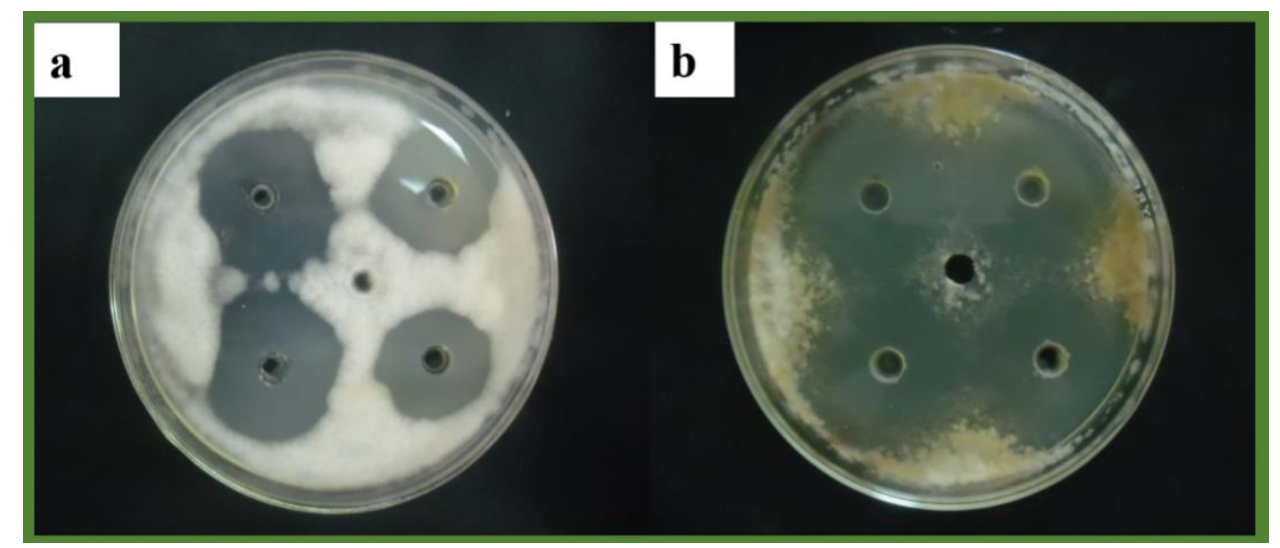

Fig 15 - Zone of inhibition of the two best fungicides against Fusarium chlamydosporum isolated from guyabano fruits. a, Captan. $b$, Difenoconazole + propiconazole.

Table 7 Zone of inhibition (mm) of the 12 fungicides tested against Fusarium chlamydosporum in guyabano fruits after 3 days incubation.

\begin{tabular}{lccc}
\hline \multirow{1}{*}{ Fungicide } & \multicolumn{3}{c}{ Zone of Inhibition (mm) } \\
\cline { 2 - 4 } & $\begin{array}{c}\text { Recommended } \\
\text { Rate }\end{array}$ & $\begin{array}{c}\text { Recommended } \\
\text { Rate }-\mathbf{2 5 \%}\end{array}$ & $\begin{array}{c}\text { Recommended } \\
\text { Rate + 25\% }\end{array}$ \\
\hline 1. Tebuconazole & $0.00^{\mathrm{f}}$ & $0.00^{\mathrm{e}}$ & $0.00^{\mathrm{c}}$ \\
2. Chlorothalonil (1) & $2.19 \mathrm{~d}^{\mathrm{e}}$ & $1.17^{\mathrm{de}}$ & $0.00^{\mathrm{c}}$ \\
3. Propineb & $7.29^{\mathrm{b}}$ & $6.33^{\mathrm{c}}$ & $2.75^{\mathrm{c}}$ \\
4. Benomyl & $0.00^{\mathrm{f}}$ & $0.00^{\mathrm{e}}$ & $0.00^{\mathrm{c}}$ \\
5. Cupric hydroxide & $0.00^{\mathrm{f}}$ & $0.00^{\mathrm{e}}$ & $0.00^{\mathrm{c}}$ \\
6. Mancozeb & $0.13^{\mathrm{f}}$ & $0.60^{\mathrm{de}}$ & $2.81^{\mathrm{c}}$ \\
7. Chlorothalonil (2) & $1.00^{\mathrm{ef}}$ & $0.58^{\mathrm{de}}$ & $0.35^{\mathrm{c}}$ \\
8. DP* & $16.25^{\mathrm{a}}$ & $18.23^{\mathrm{a}}$ & $16.00^{\mathrm{a}}$ \\
9. Captan & $17.98^{\mathrm{a}}$ & $10.69^{\mathrm{b}}$ & $16.12^{\mathrm{a}}$ \\
10. Azoxystrobin & $3.21^{\mathrm{d}}$ & $7.88^{\mathrm{bc}}$ & $9.15^{\mathrm{b}}$ \\
11. Carbendazim & $5.15^{\mathrm{c}}$ & $4.44^{\mathrm{cd}}$ & $7.21^{\mathrm{b}}$ \\
12. Thiophanate methyl & $0.00^{\mathrm{f}}$ & $0.00^{\mathrm{e}}$ & $0.00^{\mathrm{c}}$ \\
13. Control & $0.00^{\mathrm{f}}$ & $0.00^{\mathrm{e}}$ & $0.00^{\mathrm{c}}$ \\
\hline
\end{tabular}

*DP= Difenoconazole + propiconazole

Means with a common letter are not significantly different

\section{Colletotrichum gloeosporioides (2)}

Sensitivity of Colletotrichum gloeosporioides was observed on difenoconazole + propiconazole (14.92-20.02 $\mathrm{mm}$ ) in all concentrations with the highest zone of inhibitions recorded in the recommended rate $+25 \%$ (20.02 $\mathrm{mm}$ diameter). Captan was also found to be highly effective 
at recommended rate $+25 \%$ with $19.63 \mathrm{~mm}$ diameter zone of inhibition. Thiophanate methyl and mancozeb were observed to be ineffective. The two best fungicides are shown on Fig.16.Minimal effects were observed on the rest of the fungicides tested (Table 8).

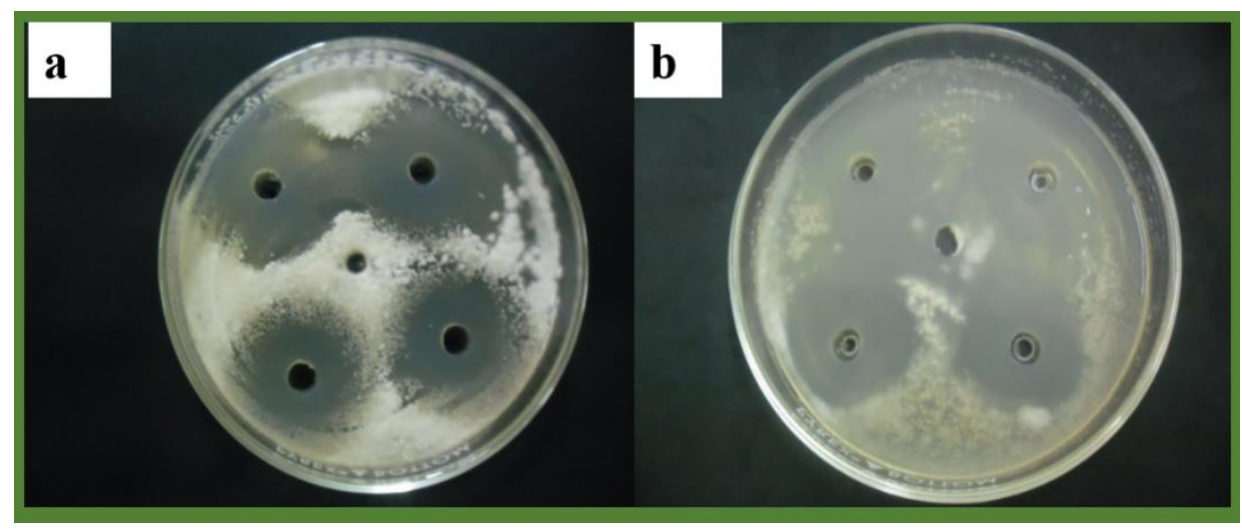

Fig 16 - Zone of inhibition of the two best fungicides against Colletotrichum gloeosporioides isolated from guyabano leaves. a, Difenoconazole + propiconazole. $b$, Captan.

Table 8 Zone of inhibition $(\mathrm{mm})$ of the 12 fungicides tested against Colletotrichum gloeosporioides (2) in guyabano leaves collected from Magtanggol after 3 days incubation.

\begin{tabular}{lccc}
\hline \multicolumn{1}{c}{ Fungicide } & \multicolumn{3}{c}{ Zone of Inhibition (mm) } \\
\cline { 2 - 4 } & $\begin{array}{c}\text { Recommended } \\
\text { Rate }\end{array}$ & $\begin{array}{c}\text { Recommended } \\
\text { Rate - 25\% }\end{array}$ & $\begin{array}{c}\text { Recommended } \\
\text { Rate 25\% }\end{array}$ \\
\hline 1. Tebuconazole & $1.54^{\mathrm{cde}}$ & $4.60^{\mathrm{c}}$ & $1.04^{\mathrm{c}}$ \\
2. Chlorothalonil 1 & $3.65^{\mathrm{bc}}$ & $3.38^{\mathrm{c}}$ & $1.19^{\mathrm{c}}$ \\
3. Propineb & $2.08^{\mathrm{cde}}$ & $2.58^{\mathrm{cd}}$ & $4.02^{\mathrm{b}}$ \\
4. Benomyl & $1.21^{\mathrm{de}}$ & $0.63^{\mathrm{def}}$ & $1.21^{\mathrm{c}}$ \\
5. Cupric Hydroxide & $0.54^{\mathrm{e}}$ & $0.88^{\mathrm{def}}$ & $0.33^{\mathrm{c}}$ \\
6. Mancozeb & $0.00^{\mathrm{e}}$ & $3.27^{\mathrm{c}}$ & $3.52^{\mathrm{b}}$ \\
7. Chlorothalonil 2 & $3.29^{\mathrm{bcd}}$ & $3.17^{\mathrm{c}}$ & $4.69^{\mathrm{b}}$ \\
8. DP* & $16.92^{\mathrm{a}}$ & $14.92^{\mathrm{a}}$ & $20.02^{\mathrm{a}}$ \\
9. Captan & $15.15^{\mathrm{a}}$ & $13.83^{\mathrm{a}}$ & $19.63^{\mathrm{a}}$ \\
10. Azoxystrobin & $3.27^{\mathrm{bcd}}$ & $3.38^{\mathrm{cde}}$ & $3.21^{\mathrm{b}}$ \\
11. Carbendazim & $0.79^{\mathrm{e}}$ & $0.27^{\mathrm{ef}}$ & $0.40^{\mathrm{c}}$ \\
12. Thiophanate Methyl & $4.75^{\mathrm{b}}$ & $8.21^{\mathrm{b}}$ & $0.00^{\mathrm{c}}$ \\
13. Control & $0.00^{\mathrm{e}}$ & $0.00^{\mathrm{f}}$ & $0.00^{\mathrm{c}}$ \\
\hline
\end{tabular}

$* \mathrm{DP}=$ Difenoconazole + propiconazole

Means with a common letter are not significantly different

\section{Colletotrichum gloeosporioides (3)}

Most prominent inhibition zone was recorded in difenoconazole + propiconazole with zone of inhibition ranging from 19.73-20.30 mm diameter and the widest was observed in recommended rate $+25 \%$ (20.30 $\mathrm{mm}$ ). Captan was also found to be highly effective in all concentrations (14.75$18.10 \mathrm{~mm}$ ) shown in Fig. 17. Thiophanate methyl was observed to be ineffective in all concentrations as well as in cupric hydroxide (Table 9). 


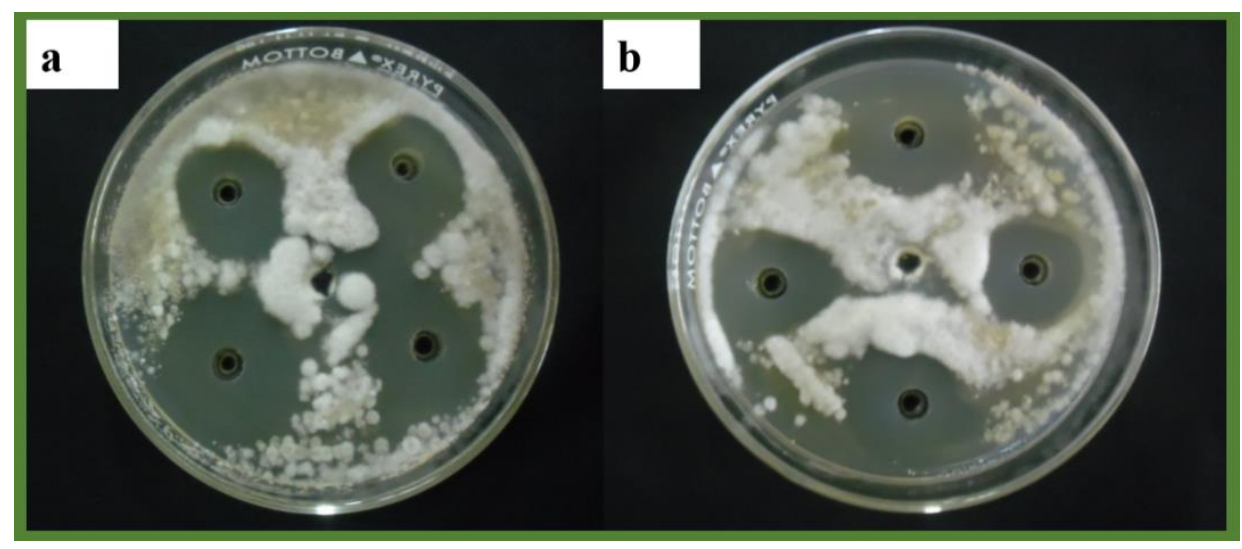

Fig 17 - Zone of inhibition of the two best fungicides against Colletotrichum gloeosporioides isolated from guyabano leaves collected from Catalanacan. a, Captan. b, Difenoconazole + propiconazole.

Table 9 Zone of inhibition ( $\mathrm{mm}$ ) of the 12 fungicides tested against Colletotrichum gloeosporioides (3) in guyabano leaves from Catalanacan after 3 days incubation.

\begin{tabular}{lccc}
\hline \multicolumn{1}{c}{ Fungicide } & \multicolumn{3}{c}{ Zone of Inhibition (mm) } \\
\cline { 2 - 4 } & $\begin{array}{c}\text { Recommended } \\
\text { Rate }\end{array}$ & $\begin{array}{c}\text { Recommended } \\
\text { Rate - 25\% }\end{array}$ & $\begin{array}{c}\text { Recommended } \\
\text { Rate 25\% }\end{array}$ \\
\hline 1. Tebuconazole & $3.17^{\mathrm{d}}$ & $1.56^{\mathrm{de}}$ & $5.60^{\mathrm{b}}$ \\
2. Chlorothalonil 1 & $1.65^{\mathrm{de}}$ & $0.00^{\mathrm{e}}$ & $2.75^{\mathrm{cd}}$ \\
3. Propineb & $2.21^{\mathrm{de}}$ & $2.48^{\mathrm{d}}$ & $3.40^{\mathrm{bc}}$ \\
4. Benomyl & $6.46^{\mathrm{c}}$ & $0.17^{\mathrm{e}}$ & $2.86^{\mathrm{cd}}$ \\
5. Cupric Hydroxide & $0.00^{\mathrm{e}}$ & $0.00^{\mathrm{e}}$ & $1.25^{\mathrm{cde}}$ \\
6. Mancozeb & $0.81^{\mathrm{de}}$ & $0.46^{\mathrm{e}}$ & $1.40^{\mathrm{cde}}$ \\
7. Chlorothalonil 2 & $3.12^{\mathrm{d}}$ & $4.52^{\mathrm{c}}$ & $2.42^{\mathrm{cde}}$ \\
8. DP* & $20.17^{\mathrm{a}}$ & $19.73^{\mathrm{a}}$ & $20.30^{\mathrm{a}}$ \\
9. Captan & $16.58^{\mathrm{b}}$ & $14.75^{\mathrm{b}}$ & $18.10^{\mathrm{a}}$ \\
10. Azoxystrobin & $0.18^{\mathrm{e}}$ & $4.33^{\mathrm{c}}$ & $3.04^{\mathrm{cd}}$ \\
11. Carbendazim & $0.54^{\mathrm{de}}$ & $0.42^{\mathrm{e}}$ & $0.63^{\mathrm{de}}$ \\
12. Thiophanate Methyl & $0.00^{\mathrm{e}}$ & $0.00^{\mathrm{e}}$ & $0.00^{\mathrm{e}}$ \\
13. Control & $0.00^{\mathrm{e}}$ & $0.00^{\mathrm{e}}$ & $0.00^{\mathrm{e}}$ \\
\hline
\end{tabular}

*DP= Difenoconazole + propiconazole

Means with a common letter are not significantly different

Difenoconazole + propiconazole and captan were the most effective against Fusarium chlamydosporum, Colletotrichum gloeosporiodes and C. acutatum. Different fungicides have different mode of action against different pathogens and captan belongs to curative broad spectrum fungicides, class phenylthalamides and degrades to thiophosgene, a compound that inhibits a number of fungal enzymes. Captan is a non-specific thiol reactant with protective and curative action that works by inhibiting respiration of numerous species of fungi including: several species of Fusarium and Colletotrichum sp. and bacteria (Mueller \& Bradley 2008). Difenoconazole + propiconazole, on the other hand, has a broad, excellent activity against all pathogen classes (Dahmen \& Staub 1992). The rest of the fungicides were less effective to the tests organisms because of their limited and specific spectrum against the test pathogen. 
Agar-well diffusion technique has been widely used to determine the fungicide resistance in populations of fungal plant pathogens. Bioassay determines dose response relationships, and compares antifungal activity with fungicides of known mode of action (Wedge 2005).

According to Bonev et al. (2008), the agar diffusion assay is one method for quantifying the ability of antibiotics to inhibit bacterial growth. The agar diffusion assay is an important technique for assessing microbial susceptibility to antibiotics, which has application worldwide over the past 50 years. It involves the application of antibiotic solutions of different concentrations to cups, wells or paper discs, placed on the surface of or punched into agar plates seeded with the test bacterial strain. Antibiotic diffusion from these sources into the agar medium leads to inhibition of bacterial growth in the vicinity of the source and to the formation of clear 'zones' without bacterial lawn. The diameter of these zones increases with antibiotic concentration.

Identification of the causal agent and prevalence of a disease is very essential for adequate and timely management of disease, which in turn depends also on accurate diagnosis and early detection of the pathogen. Therefore, the use of accurate and rapid identification techniques for early detection and identification of these pathogens is needed. Additional species-specific PCR assays and DNA sequence analyses are desirable to facilitate accurate identifications.

\section{Acknowledgements}

We extend our sincere gratitude to the Crop Protection Association of the Philippines (CPAP) for the funding support given to this research; the Institute for Climate Change and Environmental Management, Central Luzon State University (ICCEM, CLSU) and Ms. Ella Joyce S. Paragas (Department of Statistics, CAS, CLSU) for statistical analysis of the data.

\section{References}

Alvarez E, Mejia JF, Llano G, Loke J. 2005 - Characterization of Colletotrichum gloeosporioides, causal agent of anthracnose in soursop (Annona muricata) in Valle del Cauca, Colombia. Centro Internacional de Agricultura Tropical (CIAT).

Awa OC, Samuel O, Oworu OO, Sosanya O. 2012 - First report of fruit anthracnose in mango caused by Colletotrichum gloeosporioides in South-western Nigeria. International Journal of Scientific \& Technology Research 1(4), 30-34.

Baxter AP, Westhuizen GCA van der, Eicker A. 1983 - Morphology and taxonomy of South African isolates of Colletotrichum. South African Journal of Botany 2, 259-289.

Bonev B, Hooper J, Parisot J. 2008 - Principles of assessing bacterial susceptibility to antibiotics using the agar diffusion method. Journal of Antimicrobial Chemotherapy 61(6), 1295-1301.

Dahmen H, Staub T. 1992 - Protective, curative and eradicant activity of Difenoconazole against Venturia inaequalis, Cercospora arachidicola and Alternaria solani. Plant Disease 76, 774777. Doi 10.1094/PD-76-0774.

Deacon JW. 2006 - Fungal biology, 4th edition. Blackwell Publishing. pp. 205. Doi 10.1002/97811 18685068.

Dyko BJ, Mordue JEM. 1979 - Colletotrichum acutatum. CMI Descriptions of Pathogenic Fungi and Bacteria 630.

Gottsberger G. 1988 - Comments on flower evolution and beetle pollination in the genera Annona and Rollinia. Plant Systematics and Evolution 167(3-4), 189-194.

Hossain MT, Hossain SMM, Bakr MK, Rahman AKMM, Uddin SN. 2010 - Survey on major diseases of vegetable and fruit crops in Chittagong Region. Bangladesh Journal of Agricultural Research 35(3), 423-429. Doi10.3329/bjar.v35i3.6449.

Jaramillo MC, Arango GJ, González MC, Robledo SM, Velez ID. 2000 - Cytotoxicity and antileishmanial activity of Annona muricata pericarp. Fitoterapia 71(2), 183-186.

Johnston PR, Jones D. 1997 - Relationships among Colletotrichum isolates from fruit-rots assessed using rDNA sequences. Mycologia 89(3), 420-430. Doi 10.2307/3761036. 
Leslie JF, Summerell BA. 2006 - The Fusarium laboratory manual. Ames Iowa (IA): Blackwell Publishing. pp 388.

McDonald D. 1970 - Fungal infection of groundnut fruit after maturity and during drying. Transactions of the British Mycological Society 54(3), 461-472. Doi 10.1016/S0007 1536(70)80161-9.

Mueller DS, Bradley CA. 2008 - Field crop fungicides for the north central United States. Agricultural Experiment Station, Iowa State University. pp 29.

Nweke CN, Ibiam OFA. 2012 - Pre and post-harvest fungi associated with the soft rot of the fruit of Annona muricata, and their effects on the nutrient content of the pulp. American Journal of Food and Nutrition 2(4), 78-85. Doi 10.5251/ajfn.2012.2.4.78.85.

Okigbo RN, Obire O. 2009 - Mycoflora and production of wine from fruits of Soursop (Annona muricata). International Journal of Wine Research 1, 1-9. Doi 10.2147/IJWR.S4667.

Ou SH. 1985 - Rice diseases, 2nd edition. The Cambrian News (Aberystwyth). pp 380.

Pitt JI, Hocking AD. 2009 - Fungi and food spoilage, 3rd edition. Springer Dordrecht, Heidelberg, London, New York. 519 pp. Doi 10.1007/978-0-387-92207-2.

Ritchie DF. 2000 - Brown rot of stone fruits. The Plant Health Instructor. Doi 10.1094/PHI-I-20001025-01.

Setiawan B, Sulaeman A, Giraud DW, Driskell JA. 2001 - Carotenoid content of selected Indonesian fruits. Journal of Food Composition and Analysis 14(2), 169-176.

Smith BJ, Black LL. 1990 - Morphological, cultural and pathogenic variation among Colletotrichum species isolated from strawberry. Plant Disease 74, 69-76.

Sutton BC. 1992 - The genus Glomerella and its anamorph Colletotrichum In: Colletotrichum: biology, pathology and control (Baile JA, Jeger MJ, eds.), CAB International, Wallingford, UK, pp 26.

Tabasum ZA. 2012 - Soursop or guyabano: cancer-killer fruit. LUMHS online clinical discussion forum. LUMHS online article. http://www.alagad.com.ph/.../609-sour-sop-or guyabanocancer-killer-fruit.pdf. (accessed 3 July 2013).

Tamura K, Dudley J, Nei M, Kumar S. 2007 - MEGA4: molecular evolutionary genetics analysis (MEGA) software version 4.0. Molecular Biology Evolution 24, 1596-1599.

Webster J, Weber RWS. 2007 - Introduction to fungi, 3rd edition. Cambridge University Press. pp 475.

Wedge DE. 2005 - Agrochemical discovery: finding new fungicides from natural products. Acta Horticulture 677, 109-113. Doi 10.17660/ActaHorticulture.2005.677.14. 